\title{
Rizatriptan Benzoate
}

National Cancer Institute

\section{Source}

National Cancer Institute. Rizatriptan Benzoate. NCI Thesaurus. Code C47708.

The benzoate salt form of rizatriptan, a member of the triptan class agents with antimigraine property. Rizatriptan benzoate selectively binds to and activates serotonin (5HT) 1B receptors expressed in intracranial arteries, and to 5-HT 1D receptors located on peripheral trigeminal sensory nerve terminals in the meninges and central terminals in brain stem sensory nuclei. Receptor binding results in constriction of cranial vessels and inhibition of nociceptive transmission, thereby providing relief of mig raine headaches. Rizatriptan benzoate may also relief migraine headaches by inhibition of proinflammatory neuropeptide release. 